\title{
TELECOM COMMUNICATION STRUCTURES
}

\section{Sankara Ganesh Dhoopam}

General Manager (Head)-Engineering, Ramboll India PVT Ltd, Hyderabad, Telangana, India, ganeshd@ramboll.in

\begin{abstract}
The Indian tower industry has witnessed many key changes in the past few years from basic calling services to data driven services. Ongoing digital revolution, Indian government thrust on digital India and smart cities mission becomes essential to setup a robust telecom infrastructure capable of handling the surging amount of data traffic. As per government report, the mobile sector's contribution to GDP will increase to 8.2 percent by 2020 from 6.5 percent at present. Given the hypercompetitive market situation and the explosive data demand, the relevance of network infrastructure is only going to increase despite the challenges. Telecom companies current focus associated to tower infrastructure is mainly on optimization by keeping low cost tower structure, compact sites, energy savings and utilization of existing towers to the peak capacity by with or without strengthening. Also equal focus on building innovative aesthetic structures and street smart infrastructures like street light poles, smart cells for speeding up the network capabilities suitable to $4 G / 5 G$ networks and combined with other society needs like video surveillance, weather monitoring sensors, advertisement hoardings and other local traffic signal requirements.
\end{abstract}

Keywords: - Telecom tower, Tubular tower, Tower sharing, Tower strengthening, Renewable energy, Full scale tower testing, Wind loads, Colocation, Appurtenances, GSM antenna, Microwave antenna, Angular tower, optimisation etc,.

\section{INTRODUCTION}

In the past one decade, India telecom sector has registered strong growth to reach as subscriber base of $1,201.72$ Million as on October 2017, accounted for the $2^{\text {nd }}$ largest telecom network in the world with a 4,60,000+ Telecom sites and second highest number of internet users 429.23Million. This rapid growth in telecom network in the use of cellular phones for voice and data has created many telecom towers on ground and buildings having height ranges of $3 \mathrm{~m}$ to $90 \mathrm{~m}$. With the exponential data growth and growing subscriber base additional sites needed for increased capacity across technologies with $3 \%$ year average growth from now.

In a competitive market with low data tariffs and low profit levels to telecom companies, there is a strong need in exploring cost effective ways in optimizing infrastructure like mobilising optimized new telecom towers, utilizing of existing towers to the peak capacity with or without strengthening and alternative power saving solutions.

About $40 \%$ total telecom towers faces interrupted power supply say about 12 hours per day, resulting relaying on diesel generators (D.G), batteries and number of otherpower management equipment to ensure grid backup and network availability. Excessive dependence on DGs resulting environmental issue of carbon emissions. Sustainable telecommunications emphasize energy efficiency by adopting renewable energy solutions like solar and wind sources in modern telecom networks.

The Indian government is planning to develop 100 smart city projects, where IoT (Internet of things) would play a vital role in development of these cities. IoT concept primarily collect and monitor the real-time data and provide wide controlled analytics for better safety of citizens in the cities. Success of IoT depends on the speed and precise transfer of real time data, so its important to integrate mobile network associated with city monitoring equipment. From the requirement, the development of "Aesthetic smart city structures" creates huge demand in future blending into the city heritage.

Mentioning above introduction, it is important that Telecom design engineers should be aware on the cost optimizations and significance of keeping network up all the time by creating safe and sound healthy structures asmostly these structures located in public areas. There were no direct recognized India codes available for design of lattice towers $\&$ masts and current references did not cover the modern analysis and design in a sufficient manner compared to other international standards. Therefore, it is very important Telecom structural engineers should discuss on new designs, technical papers and exchanging experiences to accumulate the knowledge in one place. It is highly recommendable to include the analysis and design of communication structures 
in the education of structural engineering at the engineering universities, and young engineers starting their professional careers with introduction to this field in collegeother than already from experienced persons from the industry.

This paper highlights some of the Ramboll engineering experiences and developments in the telecom design engineering domain.

\section{TUBULAR TOWER-AN OPTIMIZED}

\section{STRUCTURAL SOLUTION}

The First step in proposing an optimised structural solution is collecting the specifications from the customer comprises of

- Location \& height of tower

- Antenna \& cables data

- Accessories requirement (Access \& cable ladder, platforms, antenna mounts, Lighting rod, aviation lamp)

Based on the specifications, designers will work on preliminary design by carrying out analysis and design by using sophisticated 3D FEM programs like iTower, RAMTower, STAAD, PLS Tower and RISA TNX programs. Preliminary design iterations done by choosing different tower geometry of varying cross sections (4 legged/3legged/6 legged/monopole), base widths, bracing pattern combinations based on the force flow, selection of profiles (Tubes/angles) for structural members etc., to work out most optimised tower design for the set of given specifications.

Optimised tower design shall not only comprises of less tower weight,less number of tower members for fabrication and installation, but it shall also require accounting for the forces coming on to the ground which decides the foundation cost and footprint for land acquisition.

As lattice towers are comparatively light structures and maximum wind pressure is chief criterion for design. Concurrence of earthquake and maximum wind pressure is unlikely to take place, in earthquake prone area the design of tower and foundations shall be checked for earthquake forces.

As the wind load is most governing for the design, it is important to calculate wind load on tower body, antennas, ladder, cables, platforms and other accessories exposed to wind facing as accurately as possible inline with stipulations provided in the loading \&design codes. While calculation of tower body wind, choosing of tower cross section either three legged or four legged and selection of profiles either angles or tubes are the key factorsdeciding the optimisation of tower and foundations.

Refer to the wind load code (IS 875 (Part 3) - 2015) for drag coefficients based on tower cross sections and profiles used, three legged tubular towers having less drag coefficients compared to three legged angular or 4-legged angular tower. So, selection of three-legged tubular has less wind load due to tower body helps in optimised tower weights and less tower reactions on foundations.

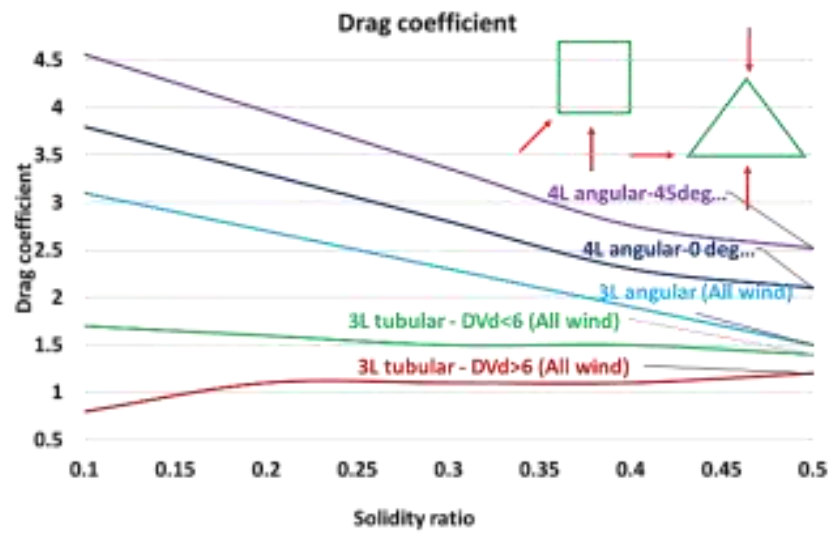

Drag coefficients for tower structures (IS 875 (Part 3))

Within the given cross-sectional area and weights comparingtubes to angles, tubes have high radius of gyration resulting lower slenderness ratio to achieve higher capacity in compressionfor the same cross sectional area profile. Selecting of angular towers needed more redundant members to economize the tower there by increasing the number of different elements for production and installation time. Still the overall weight of angular tower and foundation are higher than the tubular tower. However, tubes required special attention of welding for joints and gussets.

\begin{tabular}{|c|c|c|}
\hline \multirow[b]{2}{*}{$\begin{array}{l}\text { Example comparison } \\
\text { (Yield stress = } \\
\text { 350MPa) }\end{array}$} & L150x150x12 & T219.1x4.8 \\
\hline & 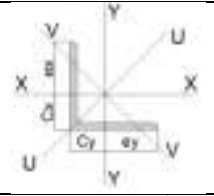 & 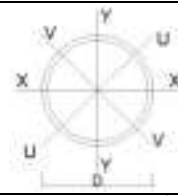 \\
\hline Cross sectional area, $\mathrm{A}$ & $34.8 \mathrm{~cm}^{2}$ & $32.32 \mathrm{~cm}^{2}$ \\
\hline $\begin{array}{l}\text { Radius of gyration, } \\
r_{x x}=r_{y y}\end{array}$ & $4.63 \mathrm{~cm}$ & $7.58 \mathrm{~cm}$ \\
\hline Radius of gyration, $r_{\mathrm{vv}}$ & $2.97 \mathrm{~cm}$ & $7.58 \mathrm{~cm}$ \\
\hline Section modulus, $\mathrm{Z}$ & $68.8 \mathrm{~cm}^{3}$ & $169.4 \mathrm{~cm}^{3}$ \\
\hline Weight & $27.3 \mathrm{~kg} / \mathrm{m}$ & $25.37 \mathrm{~kg} / \mathrm{m}$ \\
\hline $\begin{array}{l}\text { Slenderness ratio @ } \\
2500 \text { mm length on } r_{v v}\end{array}$ & 84.2 & 32.30 \\
\hline $\begin{array}{l}\text { Capacity asper IS 800- } \\
2007\left(\gamma_{\mathbf{m} 0}=\mathbf{1 . 0}\right)\end{array}$ & $636 \mathrm{kN}$ & $996 \mathrm{kN}$ \\
\hline
\end{tabular}




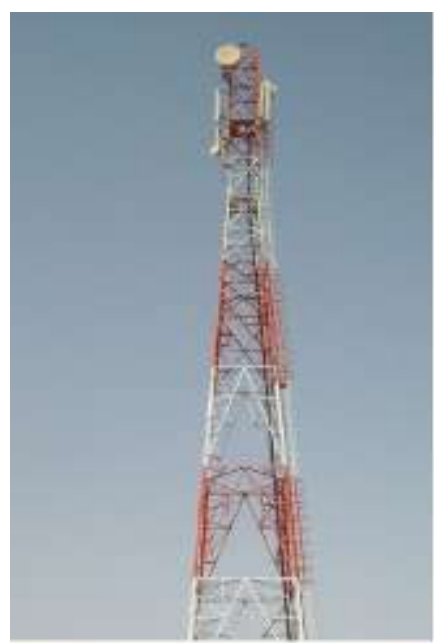

4 Legged Angular tower

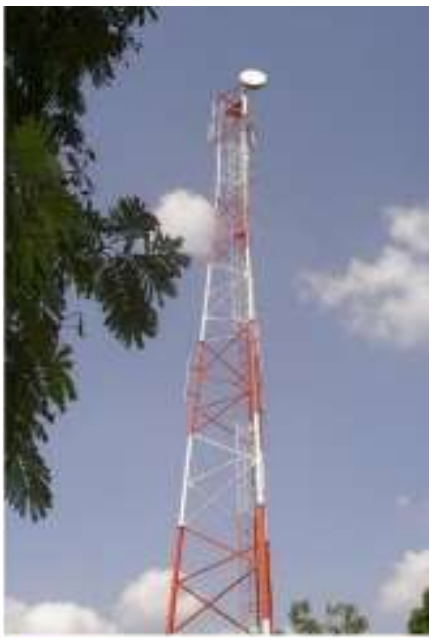

3 Legged Tubular tower

Ramboll3 Legged Tubular tower

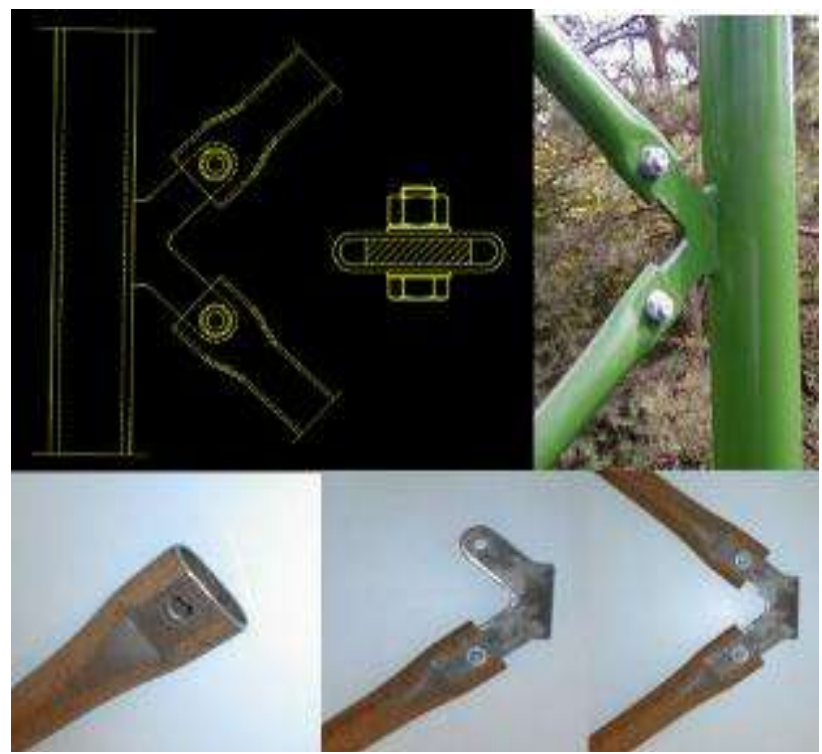

Connection details of bracing members

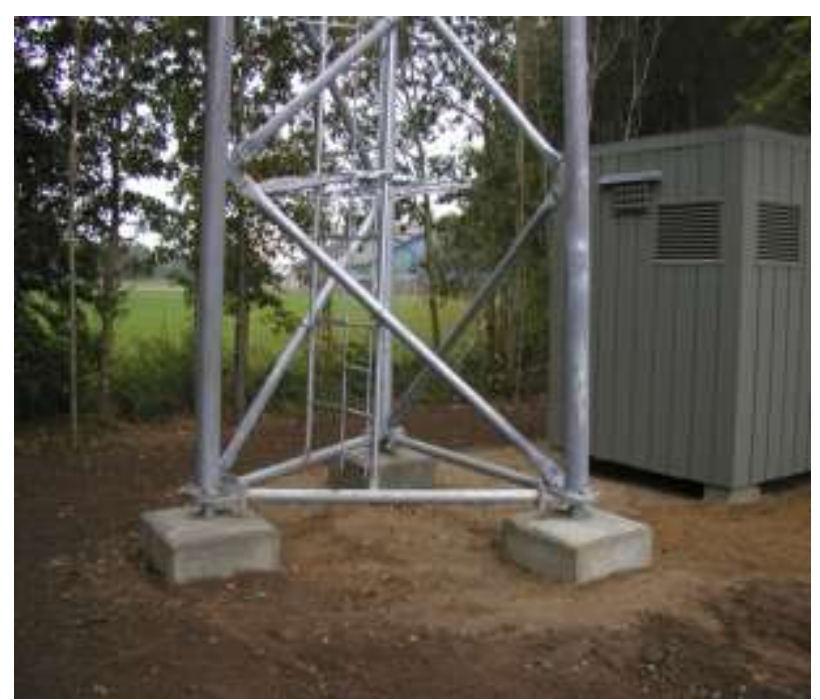

Cast in part details
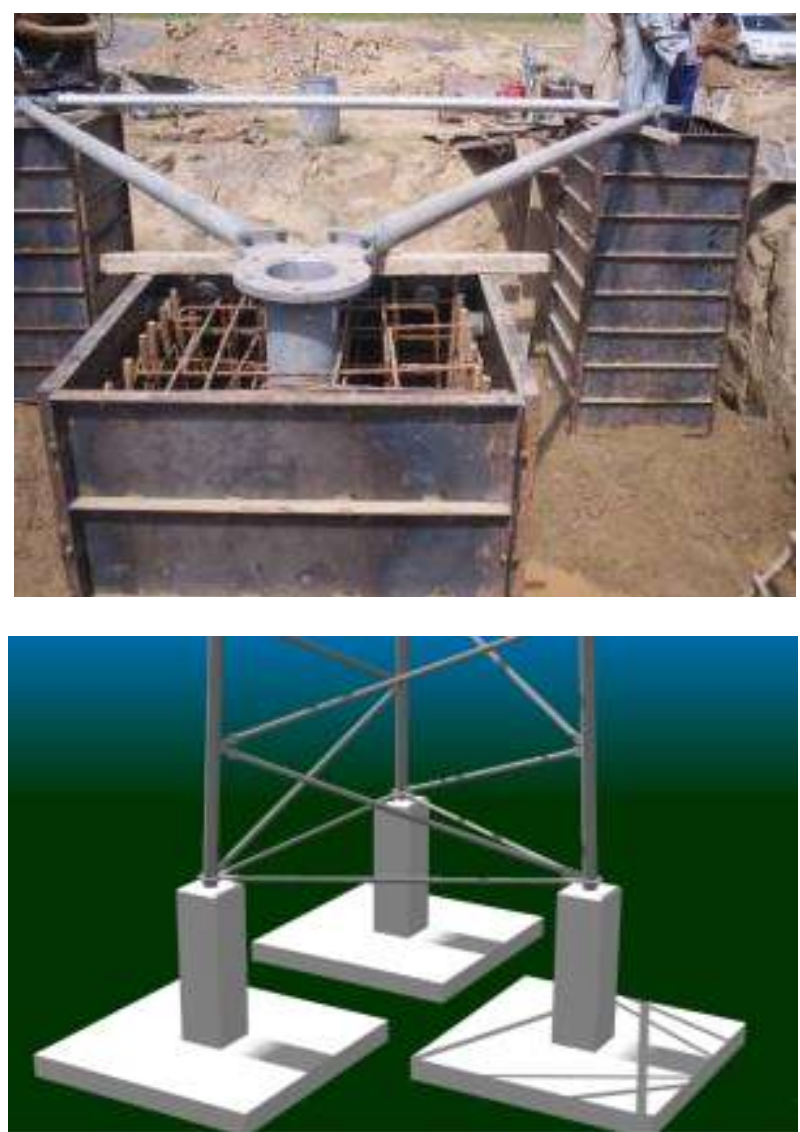

Foundation construction - Isolated/Single pads

\section{UNIQUE FEATURE WITH TUBULAR} TOWERS

Tubular towers has unique advantages compared to other configurations like low weight, simplicity, easy transport, fast assembly, low maintenance costs and less foundation costs.

Apart from tower being cost efficient and superior quality, the additional features can be integrated to the tower solution like quick build foundation, integrated equipment platform \& fence and renewable energy solutions like solar \& wind.

\subsection{Quick Build Foundation}

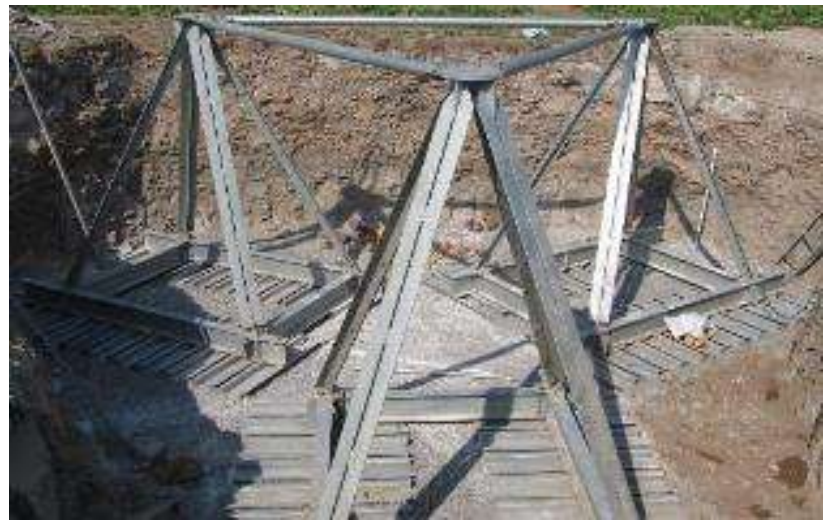




\subsection{Renewable Energy (Solar Structure on Tower)}

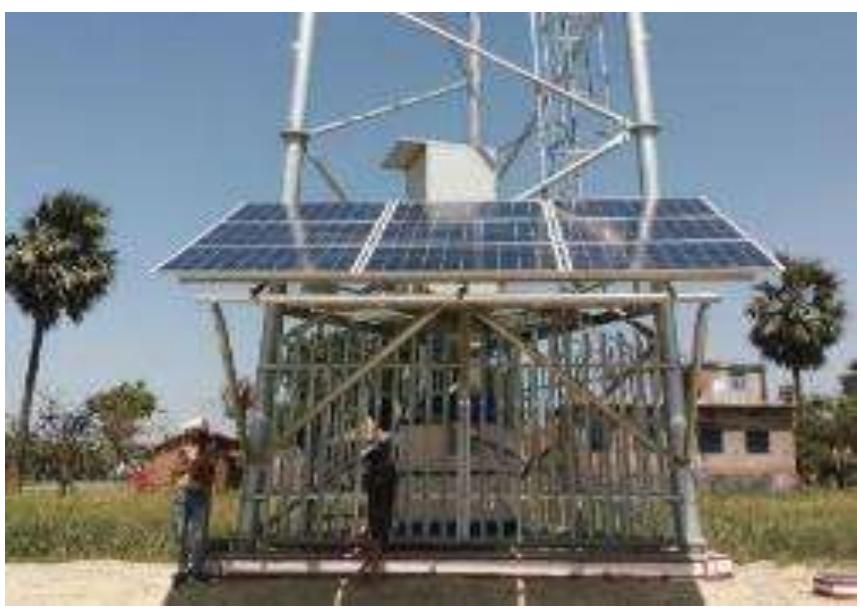

\subsection{Renewable Energy (Wind Turbine on Tower)}

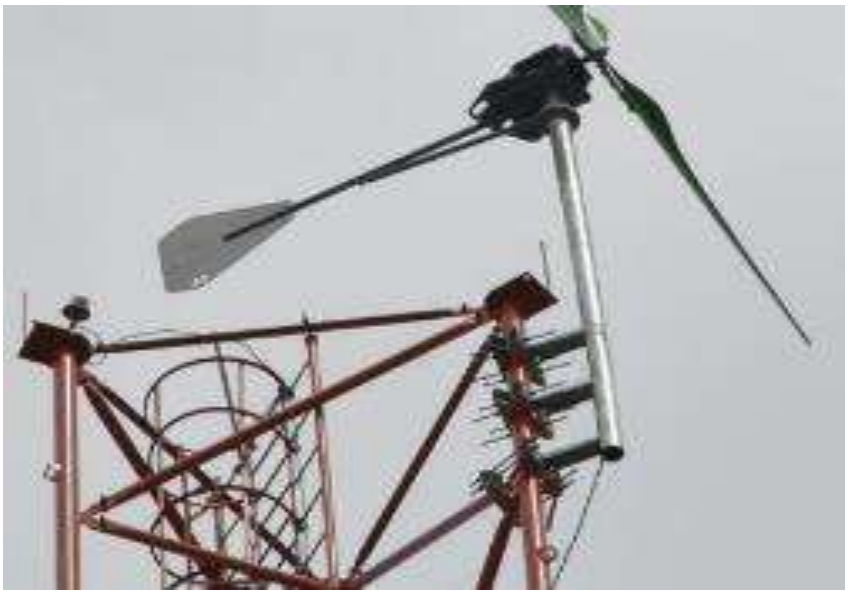

\subsection{Compact Site (Integrated Equipment Platform}

\section{\& Fence)}

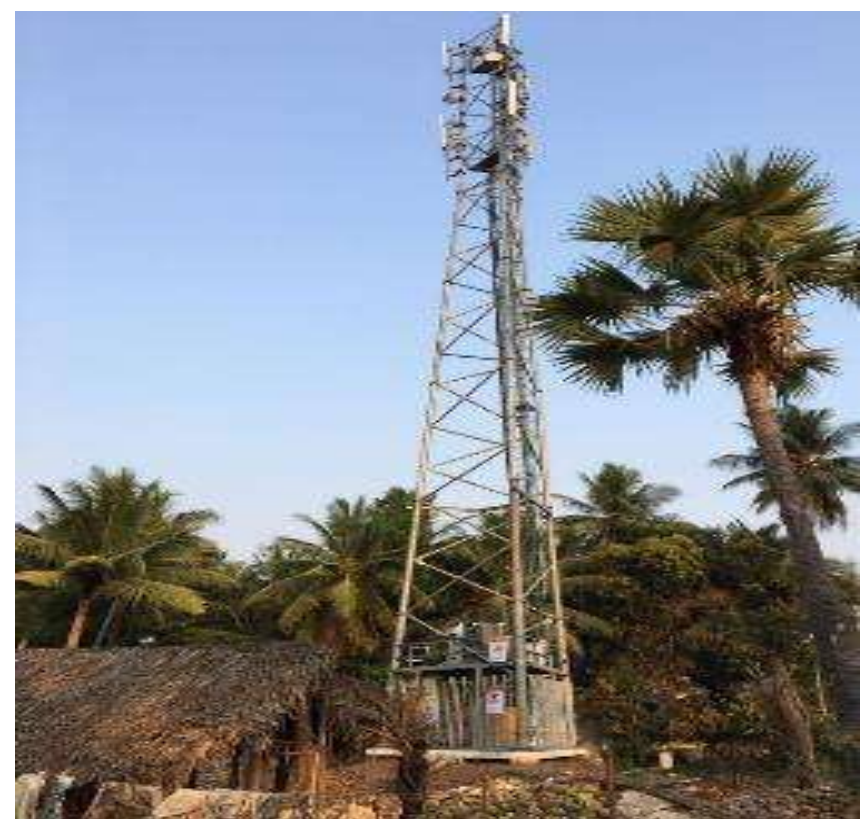

\section{STRUCTURAL ASSESSMENT \&}

\section{STRENGTHENING OF EXISTING TELECOM SITES}

Telecom operators across the world have been witnessing a decline in their profit margins and ARPUs (Average revenue per user) due to growing level of competition, not just from peers but also from content providers. There by operators/infrastructure companies are trying to reduce their operating costs utilising the existing infrastructure effectively to the optimum usage by sharing. By sharing the tower, there will be savings on renting of sites, site maintenance, manpower, electricity, air-conditioning and fuel expenses etc.

Therefore, engineering emphasis required on structural assessment of existing structures and retrofitting of structures to take additional loads of multiple operators (or) change in loading and design standards (o)r degradation of material like corrosion or operational requirements e.g., twist \& sway.

Before an existing structure is modified or additional loads are added to it, following shall be considered,

(a) The physical condition and loading of the structure shall be verified by inspection. Tower configuration and the size of structural members must be collected to map with the known tower design type from available tower design database.If there are no existing tower design documents available,complete tower structural data has to be collected to perform the structural analysis.

(b) Reporting of observations on tower structural condition like damage of members, loose members, missing members, cracks, foundation bolt $\&$ nut locking devices missing and painting conditions etc. Similar observations required on foundation concrete and soil settlement and back fill conditions.

(c) The structural adequacy of the structure shall be evaluated in accordance with applicable loading \& design requirements.

Customer tower sharing requirements from different operators required to carryout a site specific tower analysis for the existing antenna loading and proposed new antenna loading. If analysis results found tower members are overutilized on account of fully capacity or overloading of towers, the options available to make use of tower are, 1) decrease the load on tower either by removing of antennas or 2) truncating tower at top or 3) strengthen the tower members by the methodology as provide earlier. Removing of antenna or truncating of tower is not a solution from 
customer business case. Inorder to allow for further loading on tower, only option available is to strengthen the tower members and foundations.

Common structural shortfalls can be observed during the analysis for over loading of towers.

\begin{tabular}{|c|c|c|}
\hline \# & $\begin{array}{l}\text { Failure } \\
\text { conditions }\end{array}$ & Solutions \\
\hline 1 & $\begin{array}{l}\text { Compression \& } \\
\text { Tension failure } \\
\text { of members }\end{array}$ & $\begin{array}{l}\text { 1. Replacement of members } \\
\text { 2. Reinforcing of existing } \\
\text { members by } \\
\text { - Adding of members(Built -up) } \\
\text { - Star angle using clamps for } \\
\text { angular towers } \\
\text { - Adding flats using clamps for } \\
\text { tubular towers } \\
\text { 3.Converting of single lacing to } \\
\text { X-Bracings(vis-versa) }\end{array}$ \\
\hline 2 & Failure of bolts & $\begin{array}{l}\text { 1. Replacement of Member } \\
\text { with higher thickness } \\
\text { 2. Replacing of bolts with } \\
\text { higher grade }\end{array}$ \\
\hline 3 & $\begin{array}{l}\text { Slenderness }(\mathrm{L} / \mathrm{r}) \\
\text { failures }\end{array}$ & Adding secondary Members \\
\hline 4 & $\begin{array}{l}\text { Significant } \\
\text { difference in } \\
\text { main leg } \\
\text { capacities }\end{array}$ & Guyed solutions \\
\hline 5 & $\begin{array}{l}\text { Foundation } \\
\text { strengthening }\end{array}$ & $\begin{array}{l}\text { 1. Soil stabilization } \\
\text { 2. Local strengthening of pad \& } \\
\text { Chimney }\end{array}$ \\
\hline
\end{tabular}

\subsection{Analytical \&Experimental Studies Carried Out}

Recently, few researchers have studied the strengthening of steel angle members through adding of same size of built of members in star and back to back formation. While forming built up members, there is a need of drilling holes or welding to existing members. This may require temporary outage of existing services and approvals from different operators impacting revenue and customer service interruption. Hence, alternate connection arrangements are investigated to fix strengthening members. The motive of study is to fix new members by dry clamping connections. New angles or flats will be added to existing members and fixed by clamps (bolted) without any holes drilling to existing members. Experimental studies have been carried out to check the results in line with the theoretical calculated results as per codal formulas. For this study angle and pipes have been tested in compression capacity with and without strengthening.

\subsection{Laboratory Experiments}

\subsubsection{Pipe Samples with \& without Strengthening}
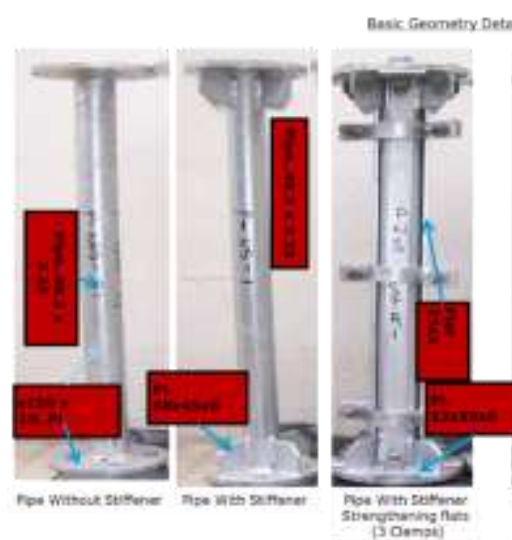

\subsubsection{Angles}

Samples

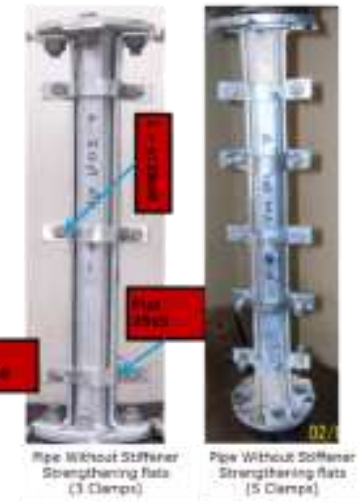

\section{Strengthening}

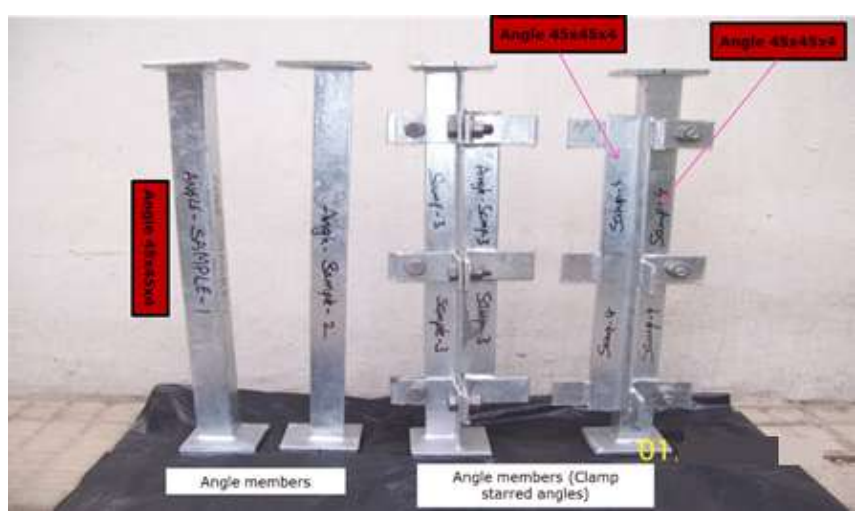

\subsubsection{Test Setup}

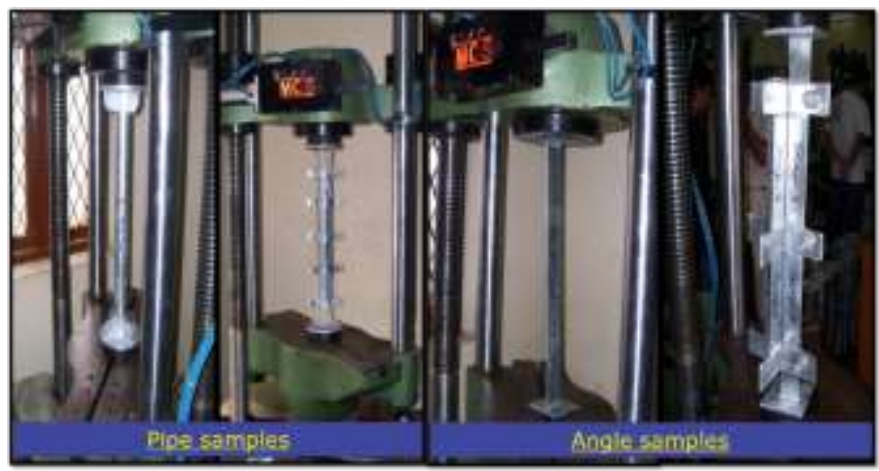

\subsection{Theoretical vs Lab Experimental Test Results}

Hot rolled and built up steel members used for carrying axial compression, usually fail by flexural buckling. The buckling strength of these members is affected by residual stresses, initial bow and accidental eccentricities of load. To account for all these factors, the strength of members subjected to compression is to be calculated by buckling class based on shape and rolling, with considering imperfection factors. 
Compressioncapacityof all these testing samples have been calculated using IS 800:2007 (Indian Code of Practice General construction in steel)and ANSI/TIA-222-G (American Code - Structural standard for antenna supporting structures and antennas)standards. Standard formulae are based on limit state design. Experimental results and theoretical results are compared in below tables and found that the capacity calculated using codes to the buckling load at failure are nearly shown the same results.

\subsubsection{Pipe Test Results}

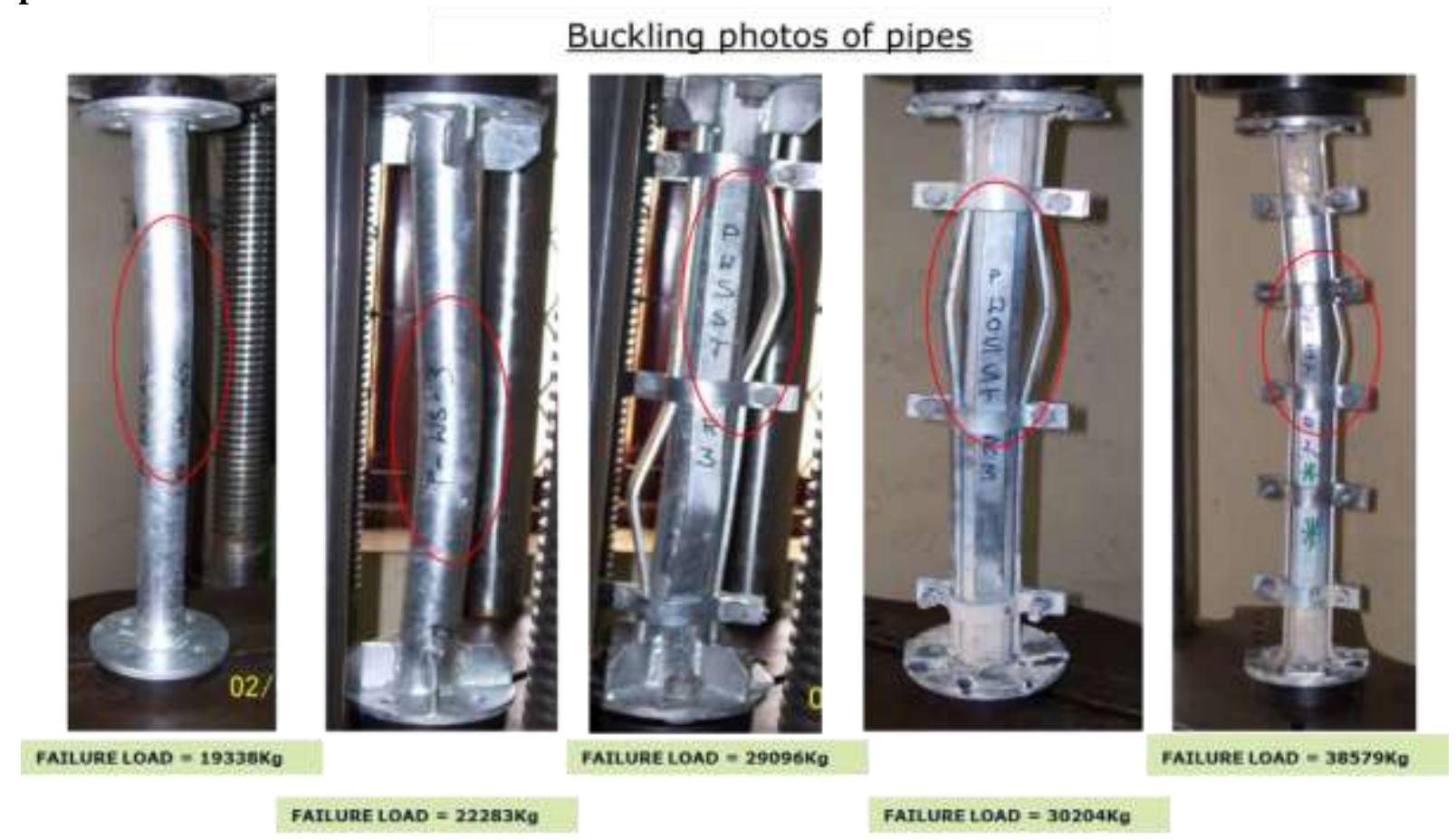

\section{Pipe Results Comparison}

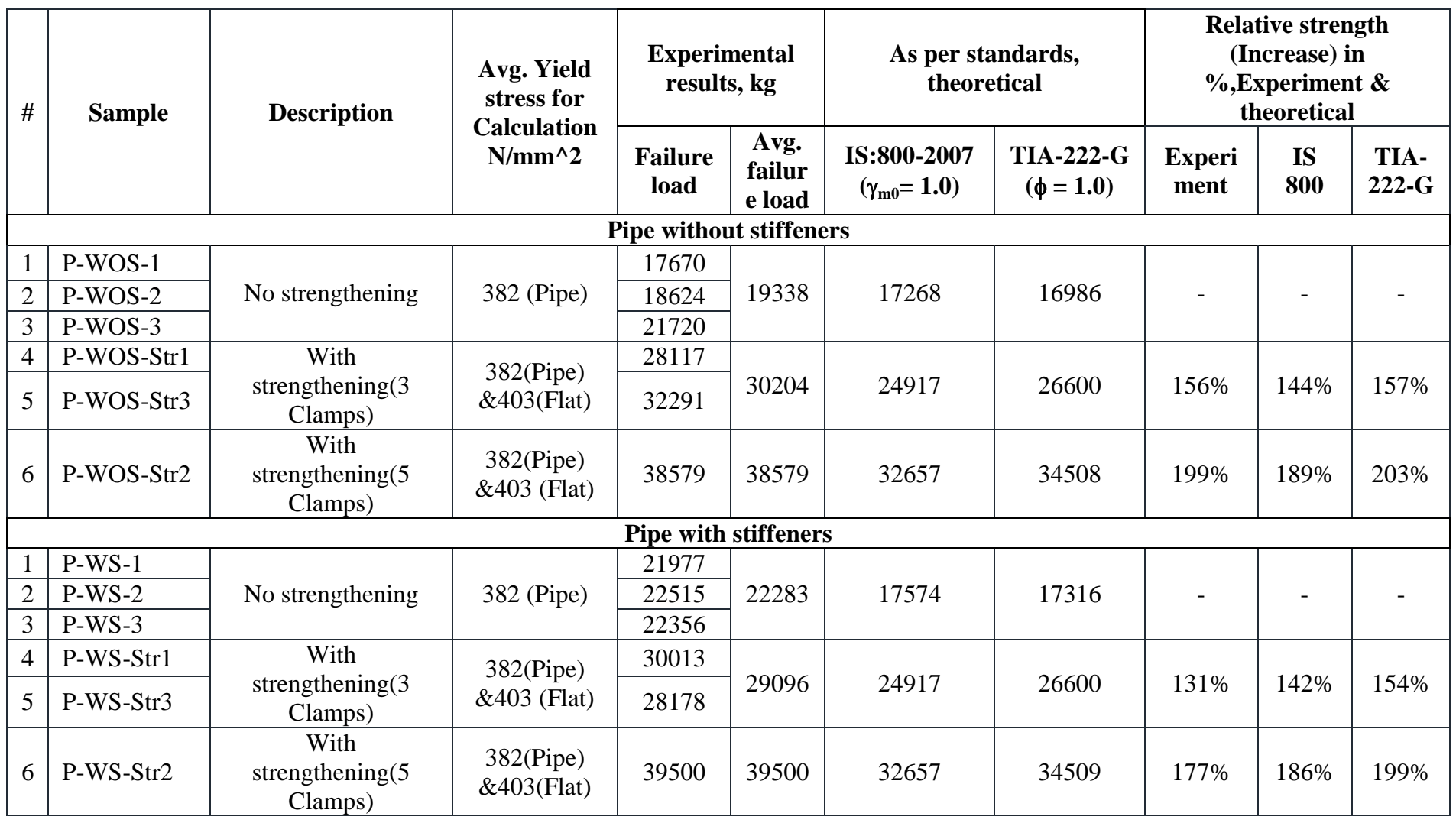




\subsubsection{Angle Test Results}

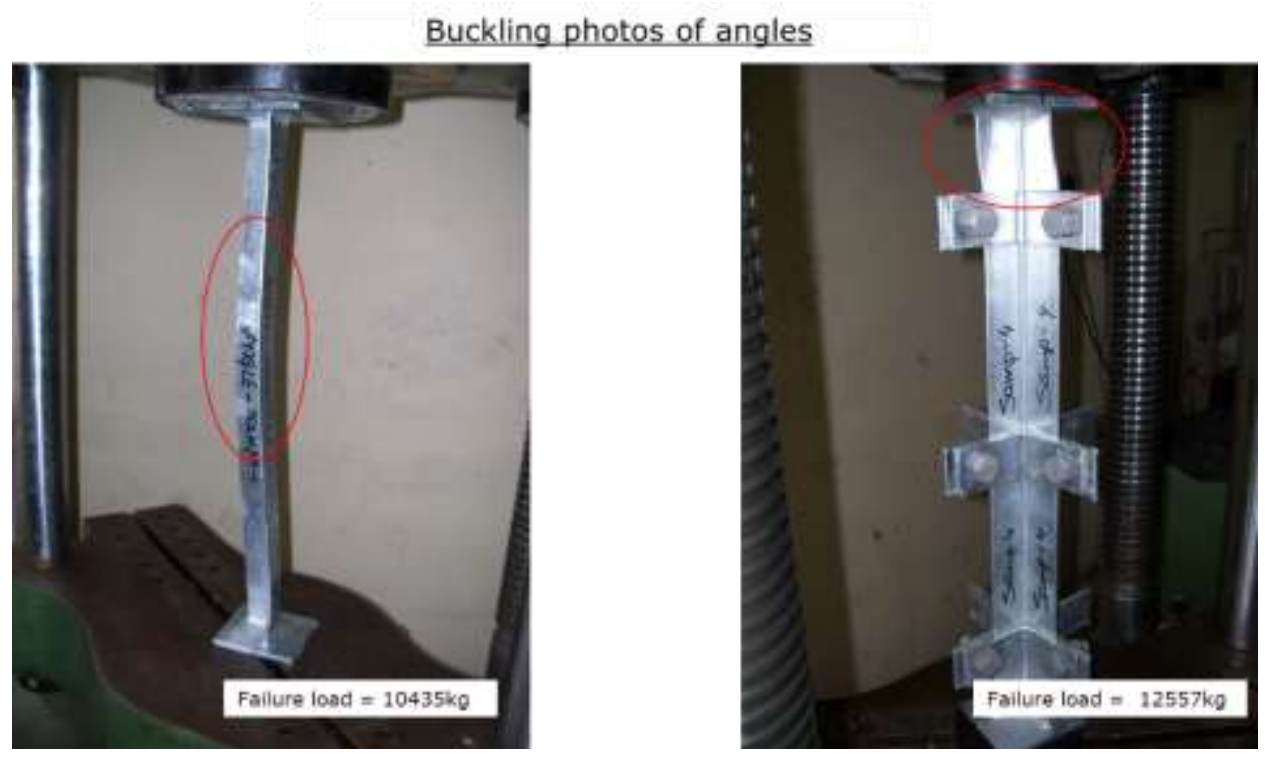

Angle Results Comparison

\begin{tabular}{|c|c|c|c|c|c|c|c|c|}
\hline \multirow[b]{2}{*}{$\#$} & \multirow[b]{2}{*}{ Sample } & \multirow[b]{2}{*}{ Description } & \multirow{2}{*}{$\begin{array}{lr}\text { Avg. Yield } & \text { for } \\
\text { stress for } \\
\text { Calculation } \\
\mathrm{N} / \mathbf{m m}^{\wedge} \mathbf{2}\end{array}$} & \multicolumn{2}{|c|}{ Experimental results } & \multicolumn{2}{|c|}{ As per standards, theoretical } & \multirow[b]{2}{*}{$\begin{array}{l}\text { Buckling } \\
\text { location }\end{array}$} \\
\hline & & & & $\begin{array}{l}\text { Failure } \\
\text { load (kg) }\end{array}$ & $\begin{array}{l}\text { Avg. } \\
\text { failure } \\
\text { load (kg) }\end{array}$ & $\begin{array}{l}\text { IS:800-2007 } \\
\left(\gamma_{\mathrm{m} 0}=\mathbf{1 . 0}\right)\end{array}$ & $\begin{array}{l}\text { TIA-222-G } \\
(\phi=1.0)\end{array}$ & \\
\hline 1 & Sample 1 & & \multirow{4}{*}{336.7} & 9251 & \multirow{2}{*}{10435} & \multirow{2}{*}{9239} & \multirow{2}{*}{10157} & Middle \\
\hline 2 & Sample 2 & Plain angles & & 11619 & & & & Middle \\
\hline 3 & Sample 3 & \multirow{2}{*}{$\begin{array}{l}\text { Clamped } \\
\text { starred angles }\end{array}$} & & 12671 & \multirow{2}{*}{12557} & \multirow{2}{*}{11898} & \multirow{2}{*}{11898} & At End \\
\hline 4 & Sample 4 & & & 12444 & & & & At End \\
\hline
\end{tabular}

Further work on full scale tower testing of $42 \mathrm{~m}$ telecom tower performed asper the customer requirement.

\section{FULL SCALE TOWER TESTING OF 42M FOUR-LEGGED ANGULAR TOWER}

In four legged angular $42 \mathrm{~m}$ tower configuration (wind speed $180 \mathrm{kmph}$ ) with all mild steel members (Yield stress = $250 \mathrm{MPa}$ ) has been observed that the main leg members and bracings are over utilised for the new loadings. Therefore, a strengthening scheme have been proposed for the main legs strengthened by star angles and bracings are strengthened by adding new members to reduce the slenderness ratio, there by increasing the member capacity. In the scheme, the new members are added by dry clamps to the existing tower using high strength bolts.

$42 \mathrm{~m}$ tower was tested for full existing + new loadings and withstood successfully. There was no failure observed in any part of the tower for full design loads (existing + new loadings). Tower was further tested for destructive loads (beyond design loads), where the tower bracing member was buckled at upper part of tower at other than strengthened portion.
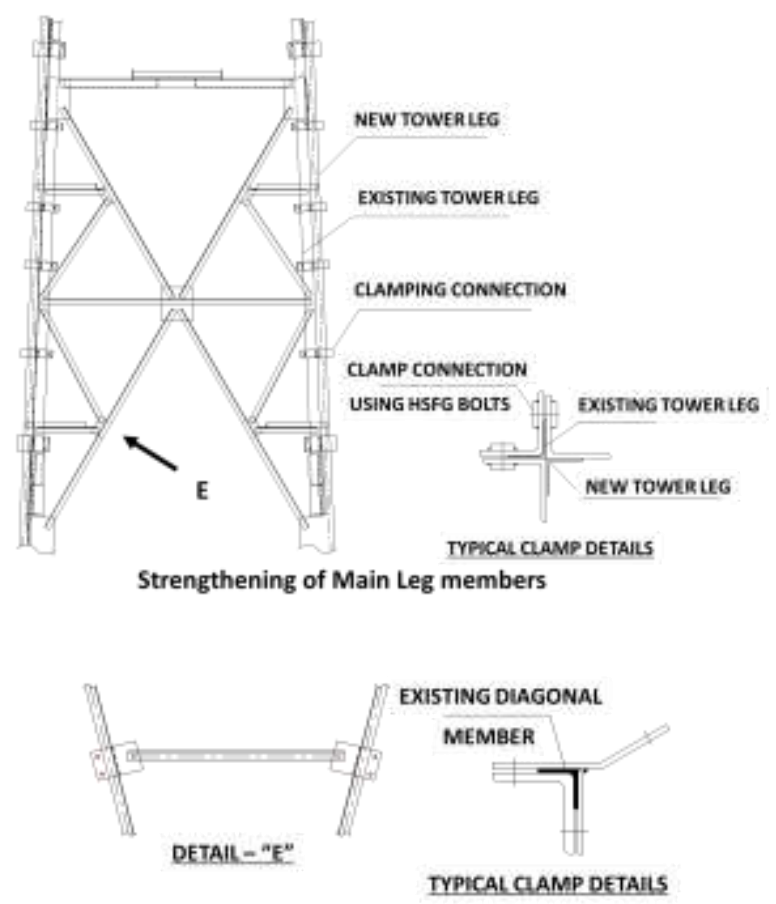

Strengthening of Diagonal members 

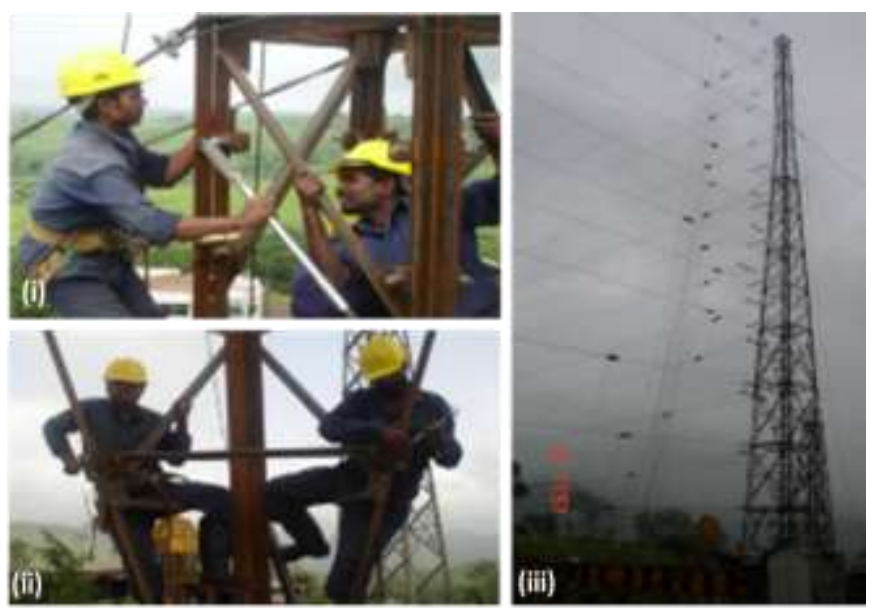

(i) Fixing of new main leg with dry clamping - high strength bolts (torque tightening)

(ii) Fixing of new member for diagonal strengthening

(iii) Full scale model testing of towerwith strengthening

By individual pipe/angle testing at laboratory and full scale tower model testing on tower test bedhas provided a good correlations with theoretical calculations.

\section{SITE SPECIFIC STRENGTHENING SOLUTIONS}

Based on the detailed structural analysis results, designers shall conclude existing tower adequacy for additional loads. In cases where, towers are not having spare capacity to take additional loads or cases of under designed towers required special review and recommendations for strengthening.

Below is an example of angular tower strengthened using start angle and pipe tower by added vertical flats using dry clamping methodology.

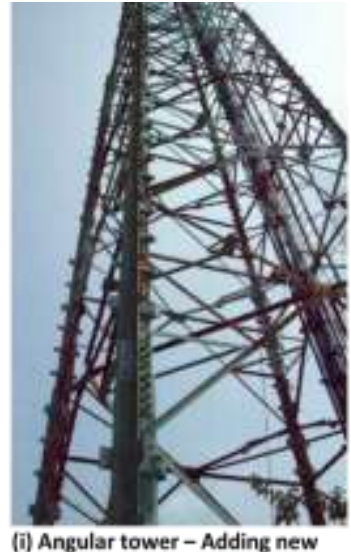

(i) Angular tower - Adding new main leg using dry clamps

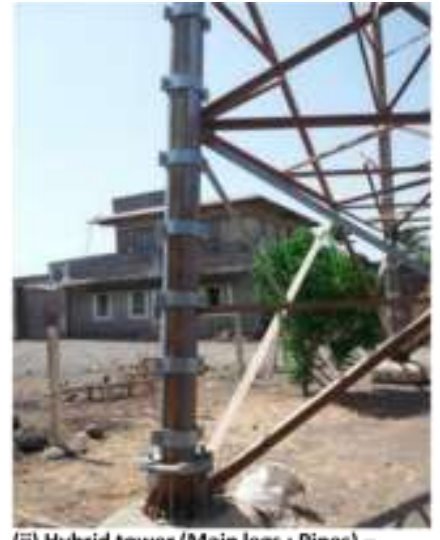

(i) Hybrid tower (Main legs : Pipes) Adding new flats with dry clamps
Strengthening of Telecom towers

\section{CONCLUSION}

This paper discusses the telecom tower optimisation, methods of strengthening of angle and pipe profiles. Even though today, we have a much better understanding of the behavior of towers, there are issues like more precise determination of the wind resistance of various towers with linear ancillaries (Antennas, ladders \& cables) by proven full scale wind tunnel tests require further investigations.

\section{REFERENCES}

[1] Støttrup-Andersen, U, “Analysis and Design of Masts and Towers", Structural World Congress, SanFrancisco, 1998

[2] Francisco, 1998.Nielsen M.G., “Advantages of using Tubular profiles in Telecommunication structures", 11th International symposium on tubular structures, August 2006, Quebec, Canada.

[3] "Tower sharing \& Reinforcement of towers and foundations" by Sankara Ganesh Dhoopam in 25th IASS WG4 Colloquium, Copenhagen, Denmark, September 2011

[4] IS 875 (Part 3) - 2015 - Design Loads (other than earthquake) for buildings and structures- Code of Practice part3 Wind Loads

[5] IS $800: 2007$ General construction in steel - Code of practice.

[6] ANSI/TIA-222-G - 2005 Structural Standard for Antenna Supporting Structures and Antennas

\section{ACKNOWLEDGMENTS}

The author gratefully acknowledged and thank the management of Ramboll India Private Limited, Hyderabad for giving the opportunity for conducting the experimental work. Any opinions, findings and conclusions or recommendations expressed in this paper are those of the Author. The author also acknowledged the thanks to the supporters, researchers and writers whose literatures was used here for supporting this research paper.

\section{BIOGRAPHIES}

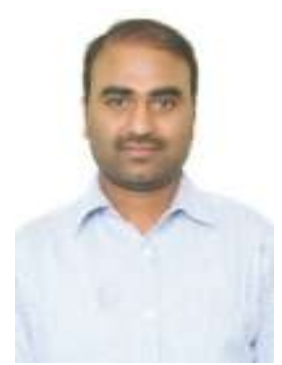

Sankara Ganesh Dhoopam working as General manager (Head) Engineering in Ramboll India, Hyderabad. He is specialised structural engineer, having 16 years of experience in design of steel lattice towers \& masts and foundations for telecom and power transmission line structures. 